\title{
The Use of GeoGebra in Disadvantaged Rural Geometry Classrooms
}

\author{
https://doi.org/10.3991/inet.v15i14.13739
}

\author{
Collen Manganyana, Sonja van Putten ${ }^{(凶)}$, Willem Rauscher \\ University of Pretoria, Groenkloof, Pretoria \\ sonja.vanputten@up.ac.za
}

\begin{abstract}
The aim of this study was to investigate how the implementation of GeoGebra by teachers who had recently attended a GeoGebra training course, impacts on learner experience and achievement. The study was conducted in four disadvantaged and under resourced schools situated in rural areas of the Mpumalanga Province of South Africa. Despite the curriculum's encouragement to use educational technology in the mathematics classroom, and evidence of the benefits of such use, literature indicates that most mathematics teachers still struggle with effective technology integration into their classrooms. Within the non-equivalent quasi-experimental design of this study, a quantitative approach was used. The conceptual framework involved the first two levels of Kirkpatrick's (1996) four level framework. Four Grade 10 classes comprising of 165 learners participated in this research. Data collection involved a questionnaire administered to the experimental group, as well as preand post-tests assessing the achievement of the learners regarding the properties of quadrilaterals administered to both the experimental and control groups. Results from the quantitative data analysis showed a significant difference in the mean scores with a mean difference of 6.5 in favour of learners taught with GeoGebra compared to a chalk and talk method. Implementation of and enthusiasm about GeoGebra had a positive influence on learner achievement. Analysis of the questionnaire responses indicated a positive reaction towards the use of GeoGebra in learning about quadrilaterals. Based on the results, it was concluded that GeoGebra as a pedagogical tool can work effectively in deep rural schools where geometry is hardly taught.
\end{abstract}

Keywords - GeoGebra; Kirkpatrick`s four level evaluation framework; geometry; quadrilaterals, disadvantaged rural schools.

\section{Introduction and the Background}

The education system in South Africa has experienced many changes since 1994, when South Africa became a democracy. Changes to the Grades $10-12$ mathematics curriculum [1] include the introduction of new concepts and topics in the curriculum. For example, Euclidean geometry became a compulsory section in the Grade 12 final examination and was examined in Paper 2 from 2014 onwards. In the previous 
curriculum, Euclidean geometry was an optional topic, and Paper 3, in which it was examined, was not compulsory for Grade 12 learners.

Although introductory geometry has always been compulsory in the General Education and Training (GET) phase (Grade R-9), most teachers teaching mathematics in the Further Education and Training (FET) phase (Grades 10-12) [1, p. 10] have not taught geometry because it was seen as difficult [2] and was often ignored, particularly in deep rural areas, which are often not on par with urban centres [3]. The inclusion of Euclidean geometry into the new curriculum [1] in the FET-band has also been a challenge to a number of mathematics teachers [4], [5], because they were not taught geometry while they were learners themselves, and because their tertiary training for the most part did not include geometry. Many teachers continue to feel uncomfortable in teaching Euclidean geometry content [6] and feel that more training on content is needed.

In order to overcome or at least ameliorate the concerns about the teaching of geometry, a strategy that may be considered is the use of educational technology like GeoGebra. Literature indicates that a different approach in teaching and learning which includes use of ICT among others [7]-[10] is not only viable, but highly recommended [11].

\section{Problem Statement}

The latest South African curriculum encourages the use of technology in mathematics classrooms (DBE, 2011). Research has shown that effective teaching in schools through the use of technology has the potential to improve learner achievement and learning [11]-[16]. Studies conducted by several researchers have concluded that most mathematics teachers still struggle with effective technology integration into their classrooms [17]-[20]. The use of educational technology in some schools in disadvantaged rural areas is almost non-existent, despite the fact that the government has supplied schools with computer laboratories and software, but there is usually no access to the Internet. However, access to GeoGebra in rural schools is not a problem since it can be used offline, but a lack of training and competence in its use may well be the problem. In spite of the challenges, increasing the effective use of dynamic tools and resources has been a national goal in South Africa since 2012. Consequently, this study investigates how the implementation of GeoGebra by teachers who had recently attended a GeoGebra training course, impacts on learner experience and achievement.

\section{Literature Review}

Although technology has been incorporated into many urban schools, unfortunately, the same cannot be assumed about their counterparts in rural areas [21], [22]. In spite of benefits such as increased learner engagement, academic performance, motivation and so forth, identified by Delen and Bulut (2011) and Gilakjani (2017), rural schools have huge challenges in this regard. In practice, the 
usual mathematics teaching and curriculum approaches still remain essentially unaltered in many South African schools, both urban and rural, regardless of state encouragement for the use of modern educational technologies [25].

Several studies investigated the effectiveness of using GeoGebra to improve learners` understanding of basic geometric concepts and academic achievement [26][33]. For instance, Bakar et al. (2015) investigated the impact of using GeoGebra on learners` mathematics performance in a Malaysian secondary school. Results from the post-test indicated that learners taught with GeoGebra achieved higher marks compared to the group where GeoGebra was not used. Bhagat and Chang (2015) conducted a similar study in India. GeoGebra was found to have a positive effect on the performance of learners. In another study conducted in Turkey, [34] it was found that teaching triangles with GeoGebra increased the academic performance of Grade 8 learners. Kushwaha, Chaurasia and Singhal (2014) found similar results. Dogan and Icel (2011), also looking at the use of GeoGebra in teaching about triangles, found statistically significant differences in teaching with GeoGebra and without, favouring GeoGebra. Overall results from all the above studies demonstrate that implementing GeoGebra can improve performance of learners [37]. Consequently, GeoGebra supported teaching methods can be recommended in the classroom because they motivate learners to learn and eventually promote an increase in their academic marks. GeoGebra can enhance learners effective understanding of geometrical concepts, hence it has a positive impact on mathematics education [38].

Despite the favourable results discussed in the literature above [39], [40], Freiman et al. (2010) and Dikovi (2009) state that there is still a need to investigate the use of such technology in the classroom as a pedagogical tool. Guided by these recommendations, it is important to conduct similar studies in the South African context focusing more specifically on how the use of GeoGebra can change learner achievement when implemented by newly trained teachers in rural disadvantaged schools.

\section{Theoretical Framework}

This study adopted Kirkpatrick's four-level model of training evaluation as the theoretical framework. According to the four levels of training evaluation by Kirkpatrick and Kirkpatrick (2010), training should be analysed and evaluated using four sequentially ordered and interrelated learning levels namely: Reaction; Learning; Behaviour and Results [41], [42]. Reaction focuses on the evaluation of learners' perceptions (reactions) or how they feel about the program and its effectiveness. As such, reaction may be described as how well learners like instruction and the training material used or parts thereof. Learning is concerned with the extent to which the learners acquire or gain the intended knowledge, skills and attitudes, as well as their commitment and confidence, based on their involvement in the learning process. Behaviour is viewed as the extent to which change in behaviour has occurred and how well learners can implement what they learnt from the training program. And finally, Results mainly focuses on achieving organisational goals that are mostly well 
understood by top management and executives hence, results are rarely relevant in educational contexts [43]. In terms of the scope of this study, only the first two levels were considered relevant and were therefore used.

\section{$5 \quad$ Design / Method}

A non-equivalent quasi experimental design was chosen involving learners from four disadvantaged rural schools. Learners were divided into two groups, namely the control group and the experimental group. Learners in Group 1 (control group) were taught the properties of quadrilaterals without GeoGebra, while learners in Group 2 (experimental group) were taught the properties of quadrilaterals with GeoGebra. The focus in both groups was on the following concepts: Properties of a square, Properties of a rectangle, Properties of a rhombus, Properties of a parallelogram and Properties of a kite. Learners in the experimental group started each lesson by investigating the properties on paper in pairs before the teacher demonstrated the properties of the geometrical shape using GeoGebra. Most of the lessons in this study were presented in the afternoons and some on Saturdays. This arrangement was agreed upon to avoid disruption of normal classes. Addition of a non-randomised control group minimised threats to internal validity.

\section{$5.1 \quad$ Research procedure}

As shown in Figure 1, learners in both groups were given a test before the intervention [44]. In this study, the intervention was the use of GeoGebra as an instructional tool in the classroom: after the pre-test, newly trained teachers in the use of GeoGebra taught their learners in the experimental group using GeoGebra. The participants in the control group were taught the same content using the traditional method (without GeoGebra). All the learners from both groups then wrote post-tests in order to establish their immediate retention and understanding of the content. After all the lessons, learners from the experimental group also completed a reflection questionnaire to gather information on how they felt about learning geometric concepts with GeoGebra thus relating the data to Level 1 of Kirkpatrick's evaluation framework. With the objective of protecting the anonymity of all the people who participated in this study as well as respecting their moral and cultural values, ethical protocols were followed during all the stages. Figure 1 presents a summary of the research procedure. 


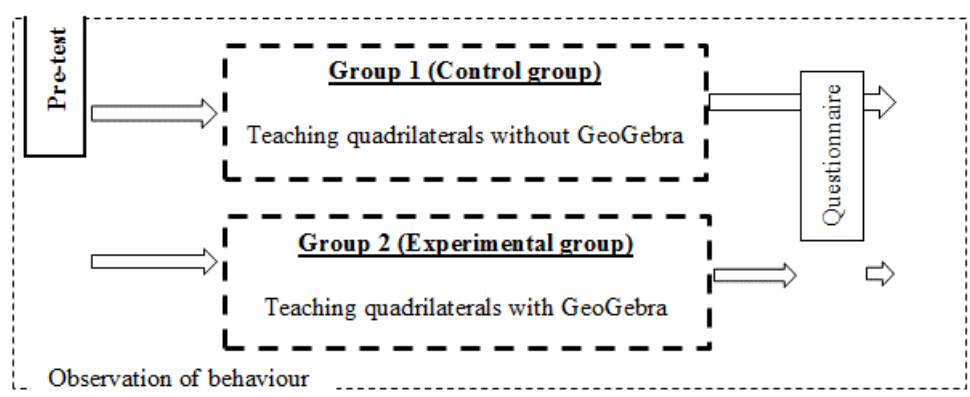

Fig. 1. The Research Procedure

\subsection{Sampling}

Learners of four Grade 10 classes in disadvantaged rural schools were sampled to participate in the quantitative phase of the study. A total of 165 learners from all four schools participated in the study. Two schools comprising 89 learners formed the experimental group (Group 2) and 76 learners from the other two schools formed the control group (Group 1).

\subsection{Data collection instruments}

Two data collection instruments namely pre- and post-tests and a questionnaire were used in this study, and are discussed as they relate to the first two levels of the Kirkpatrick model.

Pre- and post-tests: Before the intervention (learning with GeoGebra), all learners from both experimental and control groups wrote a pre-test consisting of 20 questions. The test consisted of a mixture of multiple choice questions, Yes or No questions and column-matching questions covering all the cognitive levels related to quadrilaterals as prescribed by the curriculum [1]. The purpose of the pre-test was to test the ability levels of all learners before receiving the intervention and to determine whether the two group were comparable. After the intervention, the same pre-test items were used in the post-test in both the experimental and the control groups. However, all the pretest questions were rearranged to make the post-test a little different from the pre-test. The purpose of the post-test was to determine the treatment effects of the intervention in order to determine whether learning in terms of the Kirkpatrick model took place. The instrument used for measuring learner achievement was evaluated by two independent experts, four colleagues in the mathematics department and the external facilitator who had prepared the training material for the teachers and activities for the learners. An internal reliability analysis was then performed using results of the preand post-tests to check the reliability in terms of Cronbach's alpha. The Cronbach's alpha test showed an overall score of $\alpha=.83$, showing a good internal reliability.

Questionnaire: All the learners from the experimental group also completed a reflection questionnaire. The purpose of this questionnaire was to gather information on how learners felt about learning geometric concepts with GeoGebra (Kirkpatrick 
Level 1). The learner questionnaire consisted of 19 items with responses given on a Likert-scale with three options namely; Yes, Not sure and No. The questionnaire was also used to assess their attitude, confidence and commitment towards learning with GeoGebra. More specifically, items in the questionnaire focused on evaluating how learners reacted to the GeoGebra instruction in the classroom. The learner questionnaire was initially evaluated by two independent experts and pilot tested with a group of 11 learners in Grade 10. A reliability analysis was then performed to check the reliability of 19 items in the questionnaire using Cronbach's alpha. Cronbach's alpha test showed an overall score of $\alpha=.78$ indicating that the questionnaire achieved an acceptable reliability level.

Data analysis: The Statistical Package for Social Sciences (SPSS) version 25 was used in the analysis of the data which consisted of the results from the pre- and posttests and the questionnaire. Descriptive and inferential statistics were utilised. Since the data consisted of one dependent variable (GeoGebra instruction) and one independent variable (test scores), t-tests (independent t-test and paired t-test) were used to perform statistical analysis for predictions. These tests were used to measure whether the mean differences between the scores within and across the two different groups were statistically significant.

\section{$6 \quad$ Results and Discussions}

\subsection{Learners`reactions to GeoGebra instruction: Kirkpatrick`s Level 1}

Before learners were given a post-test to write, they were requested to complete a reflection questionnaire about their reactions to the use of GeoGebra as an instructional tool and how they felt about GeoGebra usage in learning the properties of quadrilaterals. Table 1 presents the results.

Table 1. Learners` reactions to GeoGebra usage in the learning of quadrilaterals

\begin{tabular}{|c|c|c|c|c|c|c|}
\hline \multirow{3}{*}{ No } & \multirow{3}{*}{ Question } & \multicolumn{4}{|c|}{$n=89$} & \multirow[b]{3}{*}{$\begin{array}{c}\text { Total } \\
\%\end{array}$} \\
\hline & & \multicolumn{3}{|c|}{ Responses ( } & ) & \\
\hline & & $\begin{array}{l}\text { Yes } \\
(\%)\end{array}$ & $\begin{array}{l}\text { Not } \\
\text { sure } \\
(\%)\end{array}$ & $\begin{array}{l}\text { No } \\
(\%)\end{array}$ & $\begin{array}{l}\text { Did not } \\
\text { complete } \\
(\%)\end{array}$ & \\
\hline 1 & $\begin{array}{l}\text { I am more excited about learning geometry through } \\
\text { GeoGebra than pencil and paper. }\end{array}$ & 100 & 0 & 0 & 0 & 100 \\
\hline 2 & $\begin{array}{l}\text { I learnt and understood a lot more about geometric concepts } \\
\text { taught using GeoGebra than those taught using paper and } \\
\text { pencil. }\end{array}$ & 85 & 15 & 0 & 0 & 100 \\
\hline 3 & $\begin{array}{l}\text { I prefer all geometry lessons with the GeoGebra, not with } \\
\text { pencil and paper from now onwards. }\end{array}$ & 68 & 25 & 7 & 0 & 100 \\
\hline 4 & $\begin{array}{l}\text { I felt confident doing activities on geometric concepts } \\
\text { involving triangles or quadrilaterals after learning these } \\
\text { through GeoGebra. }\end{array}$ & 92 & 7 & 0 & 1 & 100 \\
\hline 5 & $\begin{array}{l}\text { I enjoyed learning geometric concepts taught using } \\
\text { GeoGebra rather than pencil and paper. }\end{array}$ & 97 & 3 & 0 & 0 & 100 \\
\hline
\end{tabular}




\begin{tabular}{|c|l|c|c|c|c|c|}
\hline 6 & $\begin{array}{l}\text { GeoGebra`s visual graphics window simplified difficult } \\
\text { geometric concepts compared to paper and pencil method. }\end{array}$ & 79 & 11 & 9 & 1 & 100 \\
\hline 7 & $\begin{array}{l}\text { I was able to visualise and answer the questions after each } \\
\text { activity. }\end{array}$ & 93 & 7 & 0 & 0 & 100 \\
\hline 8 & $\begin{array}{l}\text { I was more engaged in the learning process using GeoGebra } \\
\text { than using paper and pencil. }\end{array}$ & 85 & 14 & 0 & 1 & 100 \\
\hline 9 & $\begin{array}{l}\text { I am now able to make logical assumptions and justifications } \\
\text { when attempting to prove riders after taking the geometry } \\
\text { lessons taught using GeoGebra. }\end{array}$ & 37 & 63 & 0 & 0 & 100 \\
\hline 10 & $\begin{array}{l}\text { I am now able to form better connections between previous } \\
\text { knowledge and new knowledge taught using GeoGebra. }\end{array}$ & 92 & 3 & 3 & 2 & 100 \\
\hline 11 & $\begin{array}{l}\text { I now believe I can do well in Euclidean geometry tasks } \\
\text { (including tests) especially concepts taught using GeoGebra. }\end{array}$ & 86 & 11 & 1 & 2 & 100 \\
\hline 12 & $\begin{array}{l}\text { GeoGebra has helped me to improve my understanding of } \\
\text { geometric concepts explored after taking the lessons. }\end{array}$ & 92 & 7 & 0 & 1 & 100 \\
\hline 13 & $\begin{array}{l}\text { GeoGebra has enabled me to make connections between } \\
\text { abstract geometric concepts and real-life situations. }\end{array}$ & 82 & 13 & 3 & 2 & 100 \\
\hline 14 & $\begin{array}{l}\text { The teacher stimulated interest better in all lessons taught } \\
\text { using GeoGebra than paper and pencil lessons. }\end{array}$ & 93 & 1 & 3 & 3 & 100 \\
\hline 15 & $\begin{array}{l}\text { GeoGebra usage has enhanced my understanding of the } \\
\text { topics explored after taking the lessons. }\end{array}$ & 85 & 9 & 1 & 5 & 100 \\
\hline 16 & $\begin{array}{l}\text { I have overall appreciated the usage of GeoGebra as } \\
\text { compared to paper and pencil in learning geometrical } \\
\text { concepts after taking the lessons. }\end{array}$ & 75 & 21 & 3 & 1 & 100 \\
\hline Average \% & 83 & 14 & 2 & 1 & 100 \\
\hline
\end{tabular}

Item 1 shows that all the learners $(100 \%)$ were excited about learning geometry through GeoGebra instruction. 97\% (Item 5) of the learners revealed that they enjoyed learning through GeoGebra and $92 \%$ (Item 4) confirmed that they managed to do the activities with confidence after they were exposed to GeoGebra lessons. $85 \%$ of the learners pointed out that they learnt and understood more regarding the geometric concepts involving properties of quadrilaterals. On the other hand, it was established that a few learners $(25 \%)$ were still not sure about the continued use of GeoGebra in their lessons in place of the traditional pencil and paper method. In essence, the majority of learners expressed satisfaction with the teaching and learning method used and the content learnt.

On average, $83 \%$ of the learners indicated that GeoGebra had enhanced their understanding regarding the properties of quadrilaterals as compared to a traditional chalk and talk method and $14 \%$ were not sure. This result indicates that the participants reacted favourably to the intervention (GeoGebra instruction) in terms of Kirkpatrick`s Level 1. Overall, responses from the learners showed that learners` confidence was boosted and they were excited about learning through GeoGebra in comparison to the traditional chalk and talk method. Analysis of the questionnaire responses indicates a positive reaction towards the use of GeoGebra in learning about quadrilaterals. 


\subsection{Learners` pre and post-tests results: kirkpatrick`s level 2}

Table 2 presents the descriptive statistics for the pre and post-tests scores for the two groups.

Table 2. Groups` pre and post-test scores

\begin{tabular}{|l|c|c|c|c|c|}
\hline & N & \multicolumn{2}{|c|}{ Pre-test scores } & \multicolumn{2}{c|}{ Post-test scores } \\
\hline \multicolumn{1}{|c|}{ Group } & & Mean & Std. dev & Mean & Std. dev \\
\hline Control & 76 & 7.07 & 2.42 & 7.22 & 2.39 \\
\hline Experimental & 89 & 6.76 & 2.77 & 13.72 & 2.50 \\
\hline
\end{tabular}

Table 2 results show that the mean score $(\mu=7.07, \sigma=2.42)$ of the control group was slightly higher than the mean score $(\mu=6.76, \sigma=2.77)$ of the experimental group. In order to establish whether the two groups were similar, Levene`s test and independent samples $\mathrm{t}$ - test were performed. The results are displayed in Table 3.

Table 3. Levene`s test and Independent Samples test for pre-test scores of quadrilaterals

\begin{tabular}{|c|c|c|c|c|c|c|c|c|c|}
\hline & \multicolumn{4}{|c|}{$\begin{array}{c}\text { Levene's Test for } \\
\text { Equality of Variances }\end{array}$} & \multicolumn{5}{|c|}{ t-test for Equality of Means } \\
\hline & \multirow[t]{2}{*}{$\boldsymbol{F}$} & \multirow[t]{2}{*}{ Sig. } & \multirow[t]{2}{*}{$t$} & \multirow[t]{2}{*}{$d f$} & \multirow[t]{2}{*}{$\begin{array}{l}\text { Sig. (2- } \\
\text { tailed) }\end{array}$} & \multirow[t]{2}{*}{$\begin{array}{c}\text { Mean } \\
\text { Difference }\end{array}$} & \multirow[t]{2}{*}{$\begin{array}{l}\text { Std. Error } \\
\text { Difference }\end{array}$} & \multicolumn{2}{|c|}{$\begin{array}{c}95 \% \\
\text { Confidence } \\
\text { Interval of the } \\
\text { Difference }\end{array}$} \\
\hline & & & & & & & & Lower & Upper \\
\hline $\begin{array}{l}\text { Pre-test scores Equal } \\
\text { variances assumed }\end{array}$ & .16 & .69 & -.72 & 163 & .47 & -2.75 & .38 & -1.03 & .48 \\
\hline Equal variances not assumed & & & -.72 & 157.61 & .47 & -2.75 & .38 & -1.03 & .48 \\
\hline
\end{tabular}

The result of this test (see Table 3 ) indicate that there was no significant difference in the means $\mathrm{t}(163)=-0.72$ and $\mathrm{p}=.47$. These results suggest that for the learners in the group with GeoGebra $(\mu=6.76, \sigma=2.77)$ and the group without GeoGebra $(\mu=$ $7.07, \sigma=2.42$ ) conditions were the same. The independent t-test for the equality of means indicates that the difference in the means was not significant, given their respective deviations and $\mathrm{p}=.16$.

An independent samples $t$-test was conducted to establish if the mean of the experimental group differed from the mean of the control group. The null hypothesis and alternative hypothesis tested were:

The null hypothesis was that there was no statistically significant difference between the means of the experimental group and the control group.

The alternative hypothesis was that there was a statistically significant difference between the means of the experimental group and the control group.

The result is shown in Table 4. 
Table 4. Levene`s and Independent Samples Test for post-test scores

\begin{tabular}{|c|c|c|c|c|c|c|c|c|c|}
\hline & \multicolumn{4}{|c|}{$\begin{array}{c}\text { Levene's Test for Equality of } \\
\text { Variances }\end{array}$} & \multicolumn{5}{|c|}{ t-test for Equality of Means } \\
\hline & \multirow[t]{2}{*}{$F$} & \multirow[t]{2}{*}{ Sig. } & \multirow[t]{2}{*}{$t$} & \multirow[t]{2}{*}{$d f$} & \multirow[t]{2}{*}{$\begin{array}{l}\text { Sig. (2- } \\
\text { tailed) }\end{array}$} & \multirow[t]{2}{*}{$\begin{array}{c}\text { Mean } \\
\text { Difference }\end{array}$} & \multirow[t]{2}{*}{\begin{tabular}{|l|} 
Std. Error \\
Difference
\end{tabular}} & \multicolumn{2}{|c|}{\begin{tabular}{|c|}
$95 \%$ \\
Confidence \\
Interval of the \\
Difference \\
\end{tabular}} \\
\hline & & & & & & & & Lower & Upper \\
\hline $\begin{array}{l}\text { Post-test Equal } \\
\text { variances } \\
\text { assumed }\end{array}$ & 1.50 & .22 & 17.00 & 163 & .000 & 6.50 & .38 & 5.74 & 7.25 \\
\hline $\begin{array}{l}\text { Equal variances } \\
\text { not assumed }\end{array}$ & & & 17.06 & 160.89 & .000 & 6.50 & .38 & 5.74 & 7.25 \\
\hline
\end{tabular}

It appears from Table 4 that the results of this test indicate that there was a statistically significant difference, at the $5 \%$ level between the mean score in the two groups, so the data suggests that the mean post-test scores were different (since the pvalue $<0.05)$. The effect size for this analysis $(d=2.66)$ is found to be more than Cohen`s $(1988)$ convention for a large sample $(d=.80)$. The null hypothesis was rejected in support of the alternative hypothesis and it is concluded that the learners in the experimental group outperformed those from the control group in geometry understanding. This result indicated that the learners` level of knowledge and skills improved due to their exposure to GeoGebra instruction used by their newly trained teachers, implying that meaningful learning occurred (Kirkpatrick`s Level 2).

\section{Conclusion}

In this study it was found that learners taught with GeoGebra performed better than those taught without GeoGebra in these four rural, disadvantaged schools. Results from this study have shown that GeoGebra instruction can work effectively in deep rural schools where geometry is hardly taught by most teachers. These findings are consistent with the findings of similar studies in different contexts, as discussed in the literature review. In fact, the implementation of digital technology tools in the classroom can be described as pivotal [45]. Learners who experience deficiencies in the teaching of geometry in their school classrooms, may augment such teaching by using the Internet. However, this possibility does not exist for learners who live in deep rural, disadvantaged areas where the Internet is not available. GeoGebra can enhance geometry teaching and learning in rural schools, where it can be accessed without connecting to the Internet. This study alludes to the possibility that the issue here may indeed be the lack of training and competence in the use of GeoGebra by teachers in disadvantaged rural schools. A recommendation flowing from this study is that training courses be provided for such teachers in the workplace. 


\section{$8 \quad$ References}

[1] Department of Basic Education, "Curriculum and Assessment Policy Statement Grade 1012.," Government Printing Works, Pretoria, 2011.

[2] W. A. Olivier, "Reflection on the implementation of CAPS Mathematics in the Classroom," April, pp. 1-10, 2014.

[3] O. P. Ogundile, S. A. Bishop, H. I. Okagbue, P. O. Ogunniyi, and A. M. Olanrewaju, "Factors influencing ICT adoption in some selected secondary schools in Ogun State, Nigeria,” Int. J. Emerg. Technol. Learn., vol. 14, no. 10, pp. 62-74, 2019. https://doi.org/ $\underline{10.3991 / \text { ijet.v14i10.10095 }}$

[4] S. Van Putten, S. Howie, and G. Stols, "Making Euclidean geometry compulsory: Are we prepared?" Perspect. Educ., vol. 28, no. 4, pp. 22-31, 2010.

[5] S. W. Siyepu and T. Mtonjeni, "Geometrical Concepts in Real-Life Context: A Case of South African Traffic Road Signs," Proc. 20th Annu. Natl. Congr. AMESA Kimberly, pp. 213-222, 2014

[6] K. Masha, "AMESA news," 2015.

[7] A. Albirini, "Cultural perceptions: The missing element in the implementation of ICT in developing countries,” J. Educ. Dev. using ICT, vol. 2, no. 1, pp. 49-65, 2006.

[8] J. Anderson, "ICT Transforming Education: A Regional Guide." UNESCO: International Institute for Educational Planning, Bankok, Thailand, 2010.

[9] K. A. Bingimlas, "Barriers to the successful integration of ICT in teaching and learning environments: A review of the literature," Eurasia J. Math. Sci. Technol. Educ., vol. 5, no. 3, pp. 235-245, 2009. https://doi.org/10.12973/ejmste/75275

[10] N. Shimasaki, "Integrating ICT into classroom pedagogies: An overview of barriers within the modern classroom,” J. Initial Teach. Inq., vol. 1, pp. 28-30, 2015.

[11] M. Mushipe and U. I. Ogbonnaya, "Geogebra and Grade 9 Learners' Achievement in Linear Functions,” Int. J. Emerg. Technol. Learn., vol. 14, no. 8, pp. 206-219, 2019. https ://doi.org/10.3991/ijet.v14i08.9581

[12] C. Akintade, U.,Ogbonnaya, and L. Mogari, "Deepening the quality of mathematics learning through Computer Assisted Instruction (CAI) in Nigerian secondary schools," in Proceedings of the 21st Annual National Congress of the Association for Mathematics Education of South Africa Volume 1, 2015, pp. 83-97.

[13] G. Aksoy, "Effect of Computer Animation Technique on Students' Comprehension of the" Solar System and Beyond" Unit in the Science and Technology Course.," Mevlana Int. J. Educ., vol. 3, no. 1, pp. 40-46, 2013. https://doi.org/10.13054/mije.13.02.3.1

[14] A. Overbay, M. Mollette, and E. S. Vasu, "A Technology Plan that Works," Educ. Leadership, vol. Vol 3, pp. 56-59, 2011.

[15] D. Stoilescu, "Studying Challenges in Integrating Technology in Secondary Mathematics with Technological Pedagogical and Content Knowledge ( TPACK )," in International Conferences on Educational Technologies 2014 and Sustainability, Technology and Education 2014, 2014, pp. 59-66.

[16] M. Yigit, "A Review of the Literature: How Pre- service Mathematics Teachers Develop Their Technological , Pedagogical , and Content Knowledge.," Int. J. Educ. Math. Sci. Technol., vol. Volume 2, no. 1, pp. 26-35, 2014. https://doi.org/10.18404/ijemst.96390

[17] C. S. Chai, J. H. L. Koh, and C.-C. Tsai, "A Review of Technological Pedagogical Content Knowledge,” Educ. Technol. Soc., vol. 16, pp. 31-51, 2013.

[18] L. Y. J. Davidson, M. Richardson, and D. Jones, "Teachers' perspective on using technology as an instructional tool,” Res. High. Educ., vol. 24, pp. 1-25, 2014. 
[19] A. Escuder and M. J. Furner, "The Impact of Geogebra in Math Teacher's Professional Development," Int. Conf. Technol. Coll. Math., pp. 76-84, 2011.

[20] V. Leendertz, A. S. Blignaut, H. D. Nieuwoudt, C. J. Els, and S. Ellis, "Technological pedagogical content knowledge in South African mathematics classrooms: A secondary analysis of SITES 2006 data," Pythagoras, vol. 34, no. 2, p. 9 pages, 2013. https://doi.org/ 10.4102/pythagoras.v34i2.232

[21] E. C. Nwangwu, C. A. Obi, and E. N. Ogwu, "Integration of Information Communication Technology (ICT) in the Curriculum of Federal Unity Schools (FUS) in Nigeria: Implications for Learning," Greener J. Educ. Res., vol. 4, no. 4, pp. 091-098, 2014. https:// doi.org/10.15580/gjer.2014.4.021714113

[22] M. Mahdrum, H. Handriana, and M. Safriyanti, "Exploring Teacher Perceptions and Motivations to ICT use in Learning Activities in Indonesia," J. Inf. Technol. Educ. Res., vol. 18, pp. 293-317, 2019. https://doi.org/10.28945/4366

[23] A. P. Gilakjani, "A Review of the Literature on the Integration of Technology into the Learning and Teaching of English Language Skills," Int. J. English Linguist., vol. 7, no. 5, p. 95, 2017.

[24] E. Delen and O. Bulut, "The relationship between students' exposure to technology and their achievement in science and math,” Turkish Online J. Educ. Technol., vol. 10, no. 3, pp. 311-317, 2011

[25] D. Y. Dzansi and K. Amedzo, "Integrating ICT into Rural South African Schools: Possible Solutions for Challenges," Int. J. Educ. Sci., vol. 6, no. 2, pp. 341-348, 2014. https://doi.org/10.1080/09751122.2014.11890145

[26] S. H. Turk and D. Akyuz, "The Effects of Using Dynamic Geometry on Eighth Grade Students`Achievement and Attitude towards Triangles,” Int. J. Technol. Math. Educ. Vol, vol. 23, no. 3, pp. 95-102, 2015.

[27] Ö. Çakir, D. M. Gezgin, and P. Özkan, "Students' Opinions About the Use of Geogebra Dynamic Geometry Software : Math Lesson Sample,” May, 2017.

[28] K. A. Bakar, A. F. M. Ayub, and R. Mahmud, "Effects of GeoGebra towards students' Mathematics performance," in ICREM7 2015 - Proceedings of the 7th International Conference on Research and Education in Mathematics: Empowering Mathematical Sciences through Research and Education, 2015, pp. 180-183. https://doi.org/10.1109/ icrem.2015.7357049

[29] K. K. Bhagat and C. Chang, "Incorporating GeoGebra into Geometry learning-A lesson from India,” Eurasia J. Math. Sci. Technol. Educ., vol. 11, no. 1, pp. 77-86, 2015. https:// doi.org/10.12973/eurasia.2015.1307a

[30] P. Shadaan and K. E. Leong, "Effectiveness of Using Geogebra on Students" Understanding in Learning Circles," Malaysian Online J. Educ. Technol., vol. 1, no. 4, pp. 1-11, 2013.

[31] P. Seloraji and K. E. Leong, "Students' Performance in Geometrical Reflection Using GeoGebra," Malaysian Online J. Educ. Technol., vol. 5, no. 1, pp. 65-77, 2017.

[32] D. G. Denbel, "Students ' Learning Experiences When using a Dynamic Geometry Software Tool in a Geometry Lesson at Secondary School in Ethiopia," J. Educ. Pract., vol. 6, no. 1, 2015.

[33] R. A. Saha, A. F. M. Ayub, and R. A. Tarmizi, "The effects of GeoGebra on Mathematics Achievement: Enlightening Coordinate Geometry Learning," Procedia - Soc. Behav. Sci., vol. 8, pp. 686-693, 2010. https://doi.org/10.1016/j.sbspro.2010.12.095

[34] B. Özçakır, C. Aytekin, B. Altunkaya, and B. K. Doruk, "Effects of Using Dynamic Geometry Activities on Eighth Grade Students`Achievement Levels and Estimation 
Performances in Triangles,” Particip. Educ. Res., vol. 2, no. 3, pp. 43-54, 2015. https://doi. org/10.17275/per.15.22.2.3

[35] R. C. Kushwaha, P. K. Chaurasia, and A. Singhal, "Impact on students' achievement in teaching mathematics using geogebra," Proc. - IEEE 6th Int. Conf. Technol. Educ. T4E, pp. 134-137, 2014. https://doi.org/10.1109/t4e.2014.54

[36] M. Dogan and R. Icel, "The role of dynamic geometry software in the process of learning: GeoGebra example about triangles," Int. J. Hum. Sci., vol. 8, no. 1, pp. 1441-1458, 2011.

[37] L. C. Gweshe and J. J. Dhlamini, "The effect of using a Computer Assisted Instruction on teaching Circle Geometry in Grade 11," in ISTE International conference on Mathematics, Science and Technology Proceedings "Towards Effective Teaching and Meaningful Learning in Mathematics, Science and Technology," 2015, vol. 12, pp. 2-14.

[38] M. Hohenwarter and K. Jones, "Ways of linking geometry and algebra: the case of GeoGebra," Proc. Br. Soc. Res. into Learn. Math., vol. 27, no. 3, pp. 126-131, 2007.

[39] C. Little, "Interactive geometry in the classroom: old barriers and new opportunities," Proc. Br. Soc. Res. into Learn. Math., vol. 28, no. 2, pp. 49-54, 2008.

[40] V. Freiman, D. Martinovic, and Z. Karadag, "A Snapshot of GeoGebra Cmmunity Endeavours: Building a Reserach Agenda," in Proceedings of the First North American GeoGebra Conference, 2010, pp. 48-62.

[41] D. L. Kirkpatrick and J. D. Kirkpatrick, Evaluating Training Programs: The Four Levels, 3rd ed. San Francisco,CA: Berrett-Koehler Publishers, 2010. https://doi.org/10.1016/s10 98-2140(99)80206-9

[42] D. L. Kirkpatrick, “'Great Ideas Revisited:Revisiting Kirkpatrick`s Four-Level Model'.,” Train. Dev., vol. 50, no. 1, pp. 54-57, 1996.

[43] Z. C. Embi, T. Neo, and M. Neo, "Using Kirkpatrick' s Evaluation Model in a Multimediabased Blended Learning Environment,” J. Multimed. Inf. Syst., vol. 4, no. 3, pp. 115-122, 2017.

[44] L. B. Christensen, R. Johnson, and L. Turner, Research Methods, Design and Analysis, 12th ed. England: Pearson Education Limited, 2014.

[45] P. Jaiswal, "Integrating Educational Technologies to Augment Learners' Academic Achievements,” Int. J. Emerg. Technol. Learn., vol. 15, no. 2, pp. 145-159, 2020. https:// doi.org/10.3991/ijet.v15i02.11809

\section{Authors}

Collen Manganyana PhD Student, University of Pretoria Faculty of Education, University of Pretoria Groenkloof Campus Pretoria, 0002

Sonja van Putten Senior Lecturer (Mathematics) University of Pretoria Faculty of Education, University of Pretoria, Groenkloof Campus, Pretoria, 0002

Willem Rauscher Senior Lecturer (Technology), University of Pretoria, Faculty of Education, University of Pretoria, Groenkloof Campus, Pretoria, 0002

Article submitted 2020-02-13. Resubmitted 2020-03-20. Final acceptance 2020-03-22. Final version published as submitted by the authors. 